\title{
MEDIA FREEDOM IN KENYA in 2017: A REALITY OR A MIRAGE?
}

\author{
by Shirley Genga*
}

\section{Introduction}

Freedom of expression is one of the most crucial elements of democracy. ${ }^{1}$ Freedom of expression protects and fosters a number of values, including the pursuit of truth, the functioning of democracy and individual self-fulfilment. ${ }^{2}$

The right to express oneself extends the free will to publish with no impediment whatsoever. ${ }^{3}$ Therefore, communication devoid of external restraints does not only confirm self-actualisation and selfidentity, but also upholds the validity of the natural right given to man to conceive and say what he perceives to be right. ${ }^{4}$ Notably, a necessary concomitant of freedom of expression is media freedom. ${ }^{5}$

Media freedom is the capacity of the media to act as a barometer to call government to account vis-à-vis the Constitution of Kenya, $2010^{6}$ especially the values, spirit and ethos enshrined therein. ${ }^{7}$ So much so that countries which are strong democracies always have strong and free media. ${ }^{8}$ A free and democratic society is not possible without an independent, free and responsible media and an active civil society. ${ }^{9}$

A free media is important in the development of democratic processes in contemporary societies. The core responsibilities of the

* $\quad$ LLB, LLM (University of Nairobi, Law School).

1 AM Busair, C Pride \& AK Corsy 'Free speech, press freedom, and democracy in Ghana' in LL Mukhongo \& JW Macharia (eds) Political influence of the media in developing countries (2016) 59.

2 Freedom of Expression Institute The media and the law: A handbook for community journalists (2007) 4.

3 Busair et al (n 1 above) 59-60.

4 Busair et al (n 1 above) 60.

5 SA Jazbhay 'Media, freedom, democracy and the rule of law' SANEF Seminar (19th October 2005) 1.

6 The Constitution of Kenya, 2010.

7 Jazbhay (n 5 above) 1.

8 AM Hanan, $N$ Saleem, A Ali, \& $S$ Mukhtar 'Role of media in strengthening democracy in Pakistan: Journalists' perception' (2016) 31 South Asian Studies 333.

9 Hanan et al (n 8 above) 333. 
media should be understood to involve their roles as watchdogs, agenda setters, and gatekeepers. ${ }^{10}$

As watchdogs, the media has a responsibility to help guard the public interest, ensuring the accountability of powerful decision makers by highlighting cases of malfeasance, misadministration, and corruption, thereby strengthening the transparency and effectiveness of governance. ${ }^{11}$

In fact, the media is often referred to as the fourth branch or fourth estate of government because of its watchdog role. ${ }^{12}$ The media's key role in democratic governance has been recognised since the late 17th century, ${ }^{13}$ and remains a fundamental principle of modern-day democratic theory and practice. ${ }^{14}$

As agenda setters, the news media has a responsibility to raise awareness of pervasive social problems, helping to turn public attention to matters of common interest, to inform governing officials about social needs and to inform the international community about development challenges. ${ }^{15}$ As gatekeepers, the news media has a responsibility to reflect and incorporate the plurality of viewpoints and political persuasions in reporting, to maximise the diversity of perspectives and arguments heard in rational public deliberations, and to enrich the public sphere. ${ }^{16}$ By training the citizens and informing them about what is happening, journalists play an active role in policy-making, and contribute directly or indirectly to political life. In order to have a mature democracy the electorate needs to be well informed. ${ }^{17}$ When citizens are not informed they will not be able to constructively participate and engage with the democratic process. ${ }^{18}$ In a healthy democracy, those who disseminate information must not be fettered in their role of holding government accountable. A free media will help in building the democracy of a country. Democracy exists on a foundation of self-governance and

10 BM Obiero 'Journalism in the struggle for democracy in Kenya: Analysis of the standard and nation news coverage on freedom of the media in the Kenyan Constitution (2010)' unpublished PHD thesis Instituto Politécnico de Lisboa Escola Superior de Comunicação Social (2016) 1.

11 Obiero (n 10 above) 1.

12 As above.

13 SS Coronel 'The role of the media in deepening democracy' http:// unpan1.un.org/intradoc/groups/public/documents/un/unpan010194.pdf (accessed July 2017).

14 Coalition for the International Criminal Court 'NGO media outreach: Using the media as an advocacy tool' September 2003 http://www.iccnow.org/documents/ NGO-media training.pdf (accessed July 2017) 3.

15 Obiero (n 10 above) 1.

16 As above.

17 As above.

18 As above. 
free, responsible mass media are essential to both democracy and self-governance. ${ }^{19}$

In Kenya the role played by the media is not only highly regarded, but according to an opinion poll carried out by the Infotrak, a research consulting firm, the media is the most trusted institution in Kenya. ${ }^{20}$

A survey conducted in 2015 found that 83 percent of Kenyans had faith in the media and were satisfied with the watchdog role played by journalists. ${ }^{21}$ In 2016, another survey confirmed further that the media enjoys the level of highest trust by Kenyans. ${ }^{22}$ Yet, as scholars, we must ask the pertinent question as to whether the media deserves the high levels of trust the Kenyan public has bestowed upon it. To those to whom much is given, much is expected. Is the media really free? If so, is it playing the watchdog role that is expected of it, particularly at a time when the nation is going through a momentous period of transition with the implementation of the new Constitution? These are some of the questions this paper will attempt to answer. ${ }^{23}$

Furthermore, it is worth noting that although Kenya has improved remarkably in media freedom and is considered to have a freer media compared to other developing countries. ${ }^{24}$ The 2017 World Press Freedom Index published by Reporters Without Borders (RWB) ranks Kenya in 95th position. ${ }^{25}$ This ranking is below Malawi which is ranked in 70th position, Botswana in 48th position and South Africa in 31st position. ${ }^{26}$ Additionally, Kenya's RWB 2014 Index was placed in 90th position globally, which represents an 18 place drop from its 2013 position which illustrates a consistent improvement between 2009, when it scored 60 and in 2012, when it scored 52. ${ }^{27}$

It is evident, from the above, that the Kenyan media has been slipping in world rankings over the last few years, something is clearly not right when it comes to media freedom in Kenya. Further, according to the Freedom House Report, the Kenyan media is in a very unique position of being 'partly' free. ${ }^{28}$ This conclusion by the

19 A Ali 'Media ownership and control versus press freedom in a democratic Africa' (2015) Journal of Mass Communication Journalism 239.

20 Dr Mutunga 'Media's role in free and fair elections is critical' April 162016 http: / /www.nation.co.ke/oped/opinion/medias-role-in-free-and-fair-elections-iscritical/440808-3161330-an9oyu/index.html (accessed 1 July 2017).

21 Obiero (n 10 above) 23.

22 As above.

23 Mutunga (n 20 above).

24 JC Ghai 'What explains ranking of Kenya's freedom of media' 6 May 2017 http: / / www. thestar.co.ke/news/2017/05/06/what-explains-ranking-of-kenyas-freedomof-media_c1554230 (accessed 10 July 2017).

25 As above.

26 As above.

27 O Nyanjom, 'The impact of Kenya's legal and institutional frameworks on media freedom' 2014 https://www.article19.org/data/files/medialibrary/37750/Kenya research_report_A5_ALL_v2.pdf (accessed 2 July 2017). 
Freedom House Report results from the fact that Kenya currently finds itself in a very interesting position where media freedom exists boldly on paper, but the reality on the ground is something else. The current Constitution of Kenya which came into force on 27 August 2010, has not only been hailed as reformist, ${ }^{29}$ but it has a new and progressive Bill of Rights requiring extensive reforms to both the media and information management frameworks. ${ }^{30}$ However, the government seems to have another agenda. As will be observed below, the government has introduced several laws that, on the outside appear to be progressive and in line with the new Constitution, but upon closer inspection clearly has an agenda that undermines media freedom in Kenya. ${ }^{31}$ In the sections which follow, this paper will analyse the legal framework and social factors relevant to media freedom in Kenya.

\section{An overview of media freedom in Kenya}

\subsection{International law}

Kenya is bound to a series of international and regional legal instruments regarding media freedom. ${ }^{32}$ Firstly, Article 19 of the 1948 Universal Declaration of Human Rights (UDHR) which Kenya is a signatory to, states: ${ }^{33}$

Everyone has the right to freedom of opinion and expression; this right includes freedom to hold opinions without interference and to seek, receive and impart information and ideas through any media and regardless of frontiers.

Secondly, Kenya is a party to the International Covenant on Civil and Political Rights (ICCPR), under which Article 19 imposes legal obligations on states to protect freedom of expression and information. ${ }^{34}$ Article 19 provides that 'everyone shall have the right to hold opinions without interference, 35 and 'everyone shall have the right to freedom of expression; this right shall include freedom to seek, receive and impart information and ideas of all kinds, regardless of frontiers, either orally, in writing or in print, in the form of art, or through any other media of his choice. ${ }^{, 36}$

29 C Glinz 'Kenya's new Constitution: A transforming document or less than meets the eye?' (2011) 44(1) Verfassung und Recht in Übersee/Law and Politics in Africa, Asia and Latin America 60-80.

30 Bill of Rights in Chapter 4 of the Constitution of Kenya, 2010.

31 Nyanjom (n 27 above) 6.

32 Nyanjom (n 27 above) 9.

33 Art 19 of the UN General Assembly Universal Declaration of Human Rights, 10 December 1948.

34 Art 19 of the UN General Assembly International Covenant on Civil and Political Rights (ICCPR) 16 December 1966 UN Treaty Series.

35 Art 19(1) of the ICCPR.

36 Art $19(2)$ of the ICCPR. 
Nevertheless, the ICCPR permits governments to impose certain restrictions or limitations on freedom of expression if such restriction is provided for by law and if it is necessary for either the respect of the rights or reputations of others or for the protection of national security or of public order or of public health or morals. ${ }^{37}$

Thirdly, Kenya is also a party to the African Charter on Human and Peoples' Rights (ACHPR), ${ }^{38}$ which in Article 9 states that 'every individual shall have the right to receive information, 39 and that 'every individual shall have the right to express and disseminate his opinions within law.'40 Additionally, the ACHPR Commission's 2002 Declaration of Principles on Freedom of Expression in Africa sets out regional norms guaranteeing free expression. ${ }^{41}$ The African Commission has held that governments should not enact provisions that limit freedom of expression 'in a manner that override constitutional provisions or undermine fundamental rights guaranteed by the [Charter] and other international human rights documents. ${ }^{42}$

\subsection{National law}

\subsubsection{The Constitution}

Media Freedom in Kenya is guaranteed in Articles 33, 34, and 35 of the Constitution of Kenya. ${ }^{43}$ Article 33 provides for the right to freedom of expression, and Article 35 provides for the right to access to information, both key rights which are important elements of media freedom as you cannot have media freedom without the other two. ${ }^{44}$ Article 34 provides for media freedom in Kenya specifically, stating: ${ }^{45}$

(1) Freedom and independence of electronic, print and all other types of media is guaranteed, but does not extend to any expression specified in Article 33(2).

(2) The State shall not -

(a) exercise control over or interfere with any person engaged in broadcasting, the production or circulation of any publication or the dissemination of information by any medium; or

(b) penalise any person for any opinion or view or the content of any broadcast, publication or dissemination.

37 Art $19(3)$ of the ICCPR.

38 O Namwaya 'Not worth the risk: Threats to free expression ahead of Kenya's 2017 Elections' 30 May 2017 https://www.hrw.org/report/2017/05/30/not-worth-risk/ threats-free-expression-ahead-kenyas-2017-elections (accessed 8 July 2017) 49.

39 Art 9(1) of the Organisation for African Unity (OAU) African Charter on Human and Peoples' Rights (Banjul Charter) 27 June 1981.

40 Art 9(2) of the Banjul Charter.

41 African Charter on Human and Peoples' Rights Commission (ACHPR) Declaration of Principles on Freedom of Expression in Africa 22 October 2002.

42 Namwaya (n 38 above) 50.

43 Arts 33, 34 \& 35 of the Constitution of Kenya, 2010.

44 Arts 33 \& 35 of the Constitution of Kenya, 2010.

45 Art 34 of the Constitution of Kenya, 2010. 
(3) Broadcasting and other electronic media have freedom of establishment, subject only to licensing procedures that -

(a) are necessary to regulate the airwaves and other forms of signal distribution; and

(b) are independent of control by government, political interests or commercial interests.

(4) All State-owned media shall -

(a) be free to determine independently the editorial content of their broadcasts or other communications;

(b) be impartial; and

(c) afford fair opportunity for the presentation of divergent views and dissenting opinions.

(5) Parliament shall enact legislation that provides for the establishment of a body, which shall -

(a) be independent of control by government, political interests or commercial interests;

(b) reflect the interests of all sections of the society; and

(c) set media standards and regulate and monitor compliance with those standards.

Most importantly, the Fifth Schedule of the Constitution of Kenya stipulates that laws pertaining to media freedom should be passed within three years, i.e. August 2013. This was extended to December 2013, when the Media Council Act (MCA) ${ }^{46}$ and the Kenya Information and Communications Amendment Act (KICA) ${ }^{47}$ were passed by the National Assembly and assented to by President Uhuru Kenyatta. ${ }^{48}$

\subsubsection{MEDIA COUNCIL ACT (MCA)}

The body responsible for self-regulating the media and the conduct and discipline of journalists, is the Media Council of Kenya (MCK) which was first established by the 2007 Media Act. ${ }^{49}$

The function of the Council under the 2007 Media Act included a wide variety of functions including mediating or arbitrating disputes between the government and the media, the public and the media and intra-media, promoting and protecting freedom and independence of the media and promoting high professional standards among journalists. ${ }^{50}$

Furthermore, and of great importance, is the fact that the Media Act states that the Council shall operate without any government, political, commercial or other bias or interference. ${ }^{51}$ The Media Council is to be wholly independent and separate from the

46 Media Council Act No 46 of 2013 (MCA).

47 Kenya Information and Communications Amendment Act No 41A of 2013 (KICA).

48 Nyanjom (n 27 above) 9.

49 Sec 3 of the Media Act No 3 of 2007.

50 As above.

51 Sec 5 of the Media Act. 
government, ${ }_{52}$ political parties, organisations and commercial

However, before the Media Act, the MCK was a self-regulatory body for media stakeholders. It was only after the conclusion of agreements between the Kenyan government and the media that it was converted into a statutory body, in $2007 .{ }^{53}$ Council membership is drawn from media stakeholders in Kenya including the Media Owners Association, Kenya Union of Journalists, Kenya Correspondents Association, Kenya Editors Guild, Public Relations Society of Kenya, Kenya News Agency, Private and Public Universities, the Kenya Institute of Mass Communication and the Law Society of Kenya. ${ }^{54}$ Even though MCK led to some independence, the government's influence did not cease. It was still viewed as a quasigovernmental organisation because it depended on public funding and the government maintained control over it by appointing representatives to the $M C K{ }^{55}$

In 2013, parliament passed a new law in light of the provision in Article 34 (5) of the Constitution. ${ }^{56}$ This was achieved through the MCA which repealed the Media Act of 2007 . This new law reestablished the MCK. ${ }^{57}$ This time around although the functions of the MCK are more elaborate, the government still maintains control. ${ }^{58}$

The Cabinet Secretary has the power to appoint or reject the names provided by the selection panel, which is mandated to come up with a list of nominees for the eight member council. ${ }^{59}$ It is, thus, not farfetched to say that the buck ends with the government and this gravely endangers media freedom in Kenya.

Additionally, Section 27 of the MCA establishes a Complaints Commission which is independent from the MCK. ${ }^{60}$ The Complaints Commission's main function is to enforce the media standards set the by the MCK, and to arbitrate in disputes between: 1) public and the Media, 2) government and media, and 3) within the media (Intramedia). ${ }^{61}$ The Complaints Commission consists of seven members. ${ }^{62}$

Obiero (n 10 above) 47.

As above.

Sec 6 of Media Act Cap 411 B of 2007.

Obiero (n 10 above) 47 - 48.

Art 34(5) of the Constitution of Kenya, 2010 provides: 'parliament shall enact legislation that provides for the establishment of a body, which shall be independent of control by government, political interests or commercial interests; reflect the interests of all sections of the society; and set media standards and regulate and monitor compliance with those standards.'

Sec 5 of the MCA.

SR Kipngetich 'Freedom of the media in Kenya: An estranged concept?' Unpublished LLB Degree Dissertation Strathmore University 2016.

Secs 7(3), (10) \& (11) of the MCA.

Sec 27 of the MCA.

Sec 28(1)(b) of the MCA.

Secs 28(1)(a) \& (b) of the MCA. 
Interestingly, members of the Commission who are appointed can also be rejected by the Cabinet Secretary which clearly illustrates government involvement. ${ }^{63}$ It is evident that the government is still trying to control this regulatory body through recruitment of the Chairperson and the other members of the Complaints Commission, and still fighting for power to check the conduct of journalists. Furthermore, Section 38(1)f, 48 and 49 of the MCA gives both the Complaints Commission and Media Council wide reaching powers to not only impose jail terms, but also place heavy fines on journalists and media houses for various offences provided in the MCA. ${ }^{64}$

\subsubsection{Kenya Information and Communications Amendment Act (KICA)}

Parliament enacted KICA to address the regulation challenges posed by the need to give effect to Article 34 of the Constitution of Kenya. KICA amended the Kenya Communication and Information Act 2009 to align with the Constitutional thresholds on the independence of the media as set out in Article 34 of the Constitution. ${ }^{65}$ KIKA created the Communications Authority of Kenya (CAK) ${ }^{66}$ to replace the Communications Commission of Kenya. ${ }^{67}$ Its main functions range from licensing and regulating postal, to ensuring that the broadcasters adhere strictly to the subscribed or authorities subscribing code. ${ }^{68}$

Here, although the selection of a list of potential candidates is carried out by individuals from different sectors such as the Law Society of Kenya, to the Institute of Engineers of Kenya, ${ }^{69}$ the President and the Cabinet Secretary have the final authority under KICA to appoint the chairman and the members of the CAK. ${ }^{70}$ This is a fact that could explain why only those who are closely aligned to the government have in the past been granted both television and print licenses to operate in Kenya. ${ }^{71}$

Furthermore, a controversial section of the law is the creation of the Communications and Media Appeals Tribunal which has the power to impose heavy penalties under Section $102 .{ }^{72}$ Here again, the members of the tribunal are appointed by the Cabinet Secretary, thus

63 Secs $27(3),(4)$ \& (5) of the MCA.

64 Secs $38(1)(f), 48$ \& 49 of the MCA.

65 This itself had been an amendment to the Kenya Information and Communication Act 2 of 1998.

66 Sec 3 of KICA.

67 Kipngetich (n 58 above) 27.

68 As above.

$69 \mathrm{Sec} 6 \mathrm{~B}(2)(1)$ of KICA.

70 Sec $6 B(2)$ (9) of KICA.

71 Obiero (n 10 above) 24.

72 Obiero (n 10 above) 25. 
interfering with the independence of the tribunal which is feted with lethal power that can interfere with media freedom in Kenya. ${ }^{73}$ The mandate of this tribunal is to determine disputes against journalists or media houses and in so doing, to impose hefty fines on media houses and journalists, recommend de-registration of journalists and make any order on freedom of expression. Further, the tribunal can impose a fine of not more than 20 million Kenyan Shillings (USD $\$ 193,799$ ) on any respondent media enterprise and a fine of not more than five hundred thousand shillings on any journalist adjudged to have violated KICA. ${ }^{74}$ It can thus be argued that this one section can be used by the government to silence the media and infringe on the right to media freedom, especially seeing as the tribunal may not be independent from the government because the Cabinet Secretary has the final word on who is appointed.

Besides the MCA and KICA above which were borne from the Kenyan government reviewing specific media laws as required by the Fifth Schedule in the Constitution. ${ }^{75}$ The government seemingly overlooked the need to review other existing laws which contravene the imperatives of the Constitution and of the regional and international frameworks relating to media freedom and which Kenya is obligated to uphold. ${ }^{76}$

An example is the Books and Newspapers Act CAP 111 Revised Edition 2012 (2003). ${ }^{77}$ This Act establishes the Office of the Registrar of Books and Newspapers in the Attorney-General's Office. ${ }^{78}$ Under $\mathrm{KICA}$, new publications must seek registration from the Office of the Registrar of Books and Newspapers, deposit a cash bond of 1 million Kenyan Shillings (USD $\$ 10,000$ ) and two copies of the new publication before they are allowed to publish. ${ }^{79}$ Furthermore, Section 11 of KICA requires payment of a bond of USD $\$ 12,000$ with sureties as security towards any monetary penalty or damages that may be imposed, before authority is granted to print a newspaper. ${ }^{80} \mathrm{~A}$ second conviction for not paying a bond can result in a permanent ban on publishing a newspaper. ${ }^{8}$

KICA also provides excessive fines and imprisonment for contravention of its provision, ${ }^{82}$ as well as extensive discretion to police officers to seize any book or newspaper which is actually or

73 Sec 102(4) of KICA.

$74 \mathrm{Sec} 102 \mathrm{E}(\mathrm{f})$ Kenya Information and Communications (Amendment) Act $41 \mathrm{~A}$ of 2013.

75 Nyanjom (n 27 above) 9

76 As above.

77 Books and Newspapers Act CAP 111 Revised Edition 2012 [2003].

$78 \mathrm{Sec} 3$ of the Books and Newspaper Act.

79 Nyanjom (n 27 above) 9.

80 Sec 11(1) of the Books and Newspaper Act.

81 As above.

82 Sec 9 of the Books and Newspaper Act 
reasonably suspected to have been printed or published in contravention of the law, no matter where it is found.

Thus, as it stands, the laws that regulate media freedom in Kenya give the state a measure of control over the governing bodies they institute. The laws compromise the independence of frameworks for appointments and removal from office, and provide no safeguards for state funding while creating avenues for controlling the media bodies they establish. ${ }^{84}$

\section{Kenyan case law on media freedom}

\subsection{Coalition for Reform and Democracy (CORD) \& Another $v$ Republic of Kenya \& ten Others [2015] eKLR}

On 11 December 2014, the Parliamentary Committee on National Security and Administration sent the Security Laws (Amendment) Bill 19 of 2014 (SLAA) to parliament. ${ }^{85}$ The bill was passed against backdrop of the increased attacks targeting Kenyan civilians as a result of Kenya's invasion of Somalia in the context of military operations against Al-Shabaab in October 2011, and under the auspices of the African Union initiative of a free Somalia. ${ }^{86}$

On 18 December 2014, during a dramatic and chaotic session of parliament in which legislators exchanged blows in the parliamentary sitting while discussing the bill, parliament passed the bill. ${ }^{87}$ The following day, 19 December, President Uhuru Kenyatta signed the bill into law. ${ }^{88}$ The bill contained a wide array of amendments to 22 laws. ${ }^{89}$ However, the hastily passed security bill infringed on many basic rights and freedoms protected in Constitution as well as under international human rights law. ${ }^{90}$

83 Sec 14 of the Books and Newspaper Act.

84 Nyanjom (n 27 above) 5.

85 Security Laws (Amendment Act) 19 of 2014 (SLAA).

86 Kenya Law Reform Commission 'Security law Amendment Act Ruling' http:// www.klrc.go.ke/index.php/media-center/523-security-law-amendment-actruling (accessed 24 July 2016).

87 Kipngetich (n 58 above) 2.

88 As above.

89 The Acts which have been amended by the SLAA include: Rent Restriction Act (CAP 296), Kenya Airport Authority Act (CAP 395), Traffic Act (CAP 403), Investment Promotion Act (CAP 485), Labour Institutions Act (2012), Public Order Act (CAP 56), Extradition (continuous and foreign countries) Act (CAP 76), Penal Code (CAP 63), Criminal Procedure Code (CAP 75), National Transport Safety Authority Act (2012), Refugee Act (2006), National Intelligence Service Act (2012), Kenya Citizenship and Immigration Act (2011), National Police Service Act (2011) and Civil Aviation Act (2013), Public Benefits Organizations Act(2013), Prevention of Terrorism Act (2012), Sexual Offenses Act (2006), Registration of Persons Act (CAP 107), Evidence Act (CAP 80), Prisons Act (CAP 90), Firearms Act (Cap 114), and Radiation protection Act (Cap 243).

90 Kipngetich (n 58 above) 2. 
As a result, what followed were three consolidated petitions challenging the constitutionality of the SLAA. ${ }^{91}$ The High Court of Kenya considered the constitutionality of the provisions of the SLAA vis-a-vis the Bill of Rights. ${ }^{92}$ The court considered the question whether SLAA was unconstitutional as it violated: (1) the right to freedom of expression and the right to freedom of the media guaranteed under Articles 33 and 34; (2) the right to privacy under Article 31 ; (3) the rights of an arrested person under Article 49 and the right to fair trial under Article 50; (4) entitlement to citizenship and registration of persons under Article 12 and (5) the right to freedom of movement under Article 39 and the rights of refugees under Articles 2(5) and 2(6) of the Constitution and International Conventions. ${ }^{93}$

The controversial sections included Sections 12, 16, 26, 29, 48, 56,58 , and 64 . On the question whether the impugned provisions of the SLAA were unconstitutional for violating the Bill of Rights, the court found that eight provisions in the SLAA were unconstitutional. ${ }^{94}$ For the purposes of this paper, the inclusion of Section 12 of the SLAA which amended Section 66A of the Penal Code and Section 64 that introduces Section 30F of The Prevention of Terrorism Act are particularly important as the two touch on media freedom. ${ }^{95}$

Section 12 of SLAA creates the offence of publishing or causing to be published or distributing obscene, gory or offensive material which is likely to cause fear and alarm to the general public or disturb public peace. The offence created was a felony and if committed, the penalty is a fine not exceeding 5 million Kenyan Shillings (USD $\$ 48,450)$ or imprisonment for a term not exceeding three years or both. ${ }^{96}$

Section 64 which introduces Section 30F of the Prevention of Terrorism Act 30 of 2012, ${ }^{97}$ provided that a person who publishes or broadcasts any information which undermines investigations or security operations by the National Police Service or the Kenya Defence Forces commits an offence and is liable, upon conviction, to a fine not exceeding five million Kenyan shillings (USD \$48,450) or imprisonment for a term not exceeding three years, or both. ${ }^{98}$

The court declared Section 12 of the SLAA and Section 66A of the Penal Code unconstitutional for violating the freedom of expression

91 Kenya Law Reform Commission (n 86 above).

92 Coalition for Reform and Democracy (CORD) \& two Others $v$ Republic of Kenya \& ten others [2015] eKLR

93 Coalition for Reform and Democracy (n 92 above) para 463(c).

94 As above.

95 As above.

96 Sec $12(1)$ of the SLAA.

97 Prevention of Terrorism Act 30 of 2012

98 Kipngetich (n 58 above) 3. 
and the media guaranteed under Articles 33 and 34 of the Constitution. ${ }^{99}$

\subsection{Jacqueline Okuta \& Another $v$ Attorney General \& two Others [2017] eKLR}

The 2017 case of Jacqueline Okuta v Attorney General ${ }^{100}$ brought into focus the constitutionality of the offence of criminal defamation created under the provisions of Section 194 of the Penal Code CAP 63 Revised Edition 2014 (2012), Laws of Kenya. ${ }^{101}$

Section 194 of the Penal Code provides; ${ }^{102}$

Any person who, by print, writing, painting or effigy, or by any means otherwise than solely by gestures, spoken words or other sounds, unlawfully publishes any defamatory matter concerning another person, with intent to defame that other person, is guilty of the misdemeanour termed libel.

Article 19, an international organisation advocating for the right to freedom of expression, alongside Jaqueline Okuta and Jackson Nery, petitioned the High Court in Nairobi to declare that Section 194 was disproportionate and that it amounted to an unjustifiable limitation of freedom of expression. ${ }^{103}$ Okuta and Njeru had been charged under Section 194 of the Penal Code for publishing posts about a prominent Kenyan lawyer on a consumer protection Facebook page called 'Buyer Beware'. ${ }^{104}$ Thus, Okuta and Njeru sought a declaration that Section 194 of the Penal Code was unconstitutional and invalid; and a declaration that any continued enforcement of Section 194 against them to be held as being unconstitutional. ${ }^{105}$ That the Section unjustly violated the freedom of expression by imposing sanctions on the civil wrong of defamation which was inconsistent with the constitution, and thus was void to the extent of the inconsistency. ${ }^{106}$

The case thus raised two fundamental questions: whether or not criminal defamation is a ground on which a constitutional limitation on the rights of freedom of the expression, can be legally imposed and whether defamation law infringes the right of freedom of expression guaranteed under the constitution or whether it is one of the

99 Coalition for Reform and Democracy (n 92 above) para 463(c)(i).

100 Jacqueline Okuta \& Another v Attorney General \& two Others [2015] eKLR.

101 Penal Code CAP 63 Revised Edition 2014 (2012).

$102 \mathrm{Sec} 194$ of the Penal Code CAP 63.

103 Kenya Union of Journalist 'Reprieve for journalists as court strikes out criminal libel law' 7 February 2017 http://www.kenyaunionofjournalists.org/reprievejournalists-court-strikes-criminal-libel-law/(accessed 19 July 2017).

104 Kenya Union of Journalists (n 103 above).

105 Okuta (n 100 above) para 2.

106 Okuta (n 100 above) para 3. 
reasonable and justifiable limitations justifiable in an open democratic society? ${ }^{107}$

It was held that the petitioners had successfully demonstrated that the offence of criminal defamation was not reasonably justifiable in a democratic society, hence criminal sanctions on speech ought to be reserved for the most serious cases particularised under Article $33(2)(a)-(d)$ of the Constitution which are aimed at protecting public interest. ${ }^{108}$ Furthermore, it was held that Section 194 of the Penal Code, CAP 63, was unconstitutional and invalid to the extent that it covered offences other than those contemplated under Article $33(2)(a)$ to (d) of the Constitution and that continued enforcement of Section 194 was unconstitutional and a violation of the petitioners' fundamental right to the freedom of expression guaranteed under Article 33(1)(a) to (c) of the Constitution. ${ }^{109}$

Therefore, the prospect of criminal proceedings and a jail term of up to two years for defamation was excessive and unjustifiable in an open and democratic society, and the law created a disproportionate limit on freedom of expression. ${ }^{110}$ This was a major win for media freedom in Kenya. ${ }^{111}$ The judge reasoned that Section 194 was unnecessary as there is already an appropriate and satisfactory alternative remedy for defamation. ${ }^{112}$ The case is very important to journalists and Kenyans who have found themselves on the receiving end of this law due to utterances and comments about government officials and other powerful and influential members of Kenyan society. 113

\subsection{Robert Alai $v$ The Hon Attorney General \& Another [2017] eKLR}

In Robert Alai $v$ The Hon Attorney General \& Another the constitutionality of Section 132 of the Penal Code, CAP 63 Laws of Kenya was challenged. ${ }^{114}$

\section{Section 132 provides: ${ }^{115}$}

Any person who, without lawful excuse, the burden of proof whereof shall be upon him, utters, prints, publishes any words or does any act or thing, calculated to bring into contempt, or to excite defiance of or

107 Okuta (n 100 above) para 1.

108 Okuta (n 100 above) para 43 (ii)

109 As above.

110 Article 19 'Kenya declares criminal defamation unconstitutional' 16 February 2017 https://www.ifex.org/kenya/2017/02/16/criminal_defamation (accessed 12 July 2017).

111 Article 19 (n 110 above).

112 Okuta (n 100 above) para 39.

113 Article 19 (n 110 above).

114 Robert Alai V The Hon Attorney General \& Another [2017] eKLR.

115 Sec 132 of the Penal Code CAP 63. 
disobedience to, the lawful authority of a public officer, is guilty of offence and is liable to imprisonment for a term not exceeding three years.

On 17 December 2014,

Robert Alai, the petitioner [was] arraigned before the Chief Magistrate's Court at Kiambu, [and was] charged with the offence of undermining the authority of a Public Officer Contrary to Section 132 of the Penal Code. Particulars of the offence stated that; while using the open source website Twitter, the petitioner posted the words 'Insulting Raila (opposition Leader) is what Uhuru (the current president of Kenya) can do. He hasn't realised the value of the Presidency. Adolescent President. This seat needs Maturity' which publication was calculated to bring into contempt the lawful authority of the President of the Republic of Kenya. ${ }^{116}$

The petitioner believed that the charge was a violation of his constitutional rights and filed the petition against the Attorney General and the Director of Public Prosecution, ${ }^{117}$ and sought a declaration that Section 132 of the Penal Code was unconstitutional and invalid, and that the continued enforcement of the section against him was unconstitutional. ${ }^{118}$ 'On 17th May, 2016, Article 19 was enjoined in these proceedings as an interested party, whose participation was limited to filing and highlighting of submissions.'119

In this case, the High Court declared Section 132 was unconstitutional and that the continued enforcement of Section 132 of the Penal Code against the petitioner was unconstitutional and a violation of his fundamental right to freedom of expression. ${ }^{120}$

\subsection{Nation Media Group Limited \& six Others v Attorney General \& nine others [2016] eKLR}

The above three cases were major wins for media freedom in Kenya, however the biggest loss was the 2016 case where the constitutionality of the Kenya Information and Communication (Amendment) Act (KICA) and the Media Council Act (MCA), as discussed above, was challenged. ${ }^{121}$ The two media laws were passed in December 2013, and immediately after received a significant amount of backlash from the media fraternity and human rights

116 Alai (n 114 above) para 1.

117 As above.

118 As above.

119 Alai (n 114 above) para 3.

120 Alai (n 114 above) para 62(1).

121 Nation Media Group Limited \& six Others $v$ Attorney General \& nine Others [2016] eKLR http://kenyalaw.org/caselaw/cases/view/122358 (accessed 24 August 2017). 
activists. ${ }^{122}$ This led to a January 2014 constitutional challenge by a coalition of media stakeholders that saw the Kenyan High Court issue an injunction against the full operation of the laws, with a hearing date set for 16 October 2014. ${ }^{123}$

The case, Nation Media Group Limited \& six Others $v$ Attorney General \& nine Others, challenged the constitutionality of Sections $38(1)(f)$ and $(h)$ of the MCA and Sections 102E(1)(f) and $(h)$ of the KICA on the basis that the two provisions contravened Articles 29 and 34 of the Constitution. ${ }^{124}$

A key contention in the KICA was the creation of the Multi Media and Appeals Tribunal, which would be top heavy with government appointees, and which have the authority to grant hefty fines of 500,000 Kenya Shillings (USD \$4844) to any journalist and 20 million Kenya Shillings (USD $\$ 193,799$ ) against any media outlet deemed to be in violation of that Act. ${ }^{125}$

The court found that both sections are constitutional. ${ }^{126}$ Consequently, the Complaints Commission created by the MCA within the Media Council of Kenya, which also has the authority to impose extreme sanctions against journalists was validated by the ruling. Thus Section 38(1) (f) of the MCA and Sections $102 \mathrm{E}(1)$ (f) and (h) of the KICA, which both include penalties for journalists, will severely constrain media freedom in Kenya and make it difficult for the media to play a watchdog role aimed at holding leaders and public institutions accountable. ${ }^{127}$ Also the ruling means journalists can be fined up to 500, 000 Kenya Shillings (USD \$4844) and media companies up to 20 million Kenya Shillings (USD \$193,799) if a new governmentregulated board finds them in breach of a government-dictated code of conduct. ${ }^{128}$ This will make journalists and media houses shy away from critical reporting and might kill investigative journalism for fear of heavy fines that are handed over by the MCA and the Communications and Media Appeals Tribunal, two bodies which are both under the control of government as illustrated above. ${ }^{129}$

122 M Murimi 'Blow to media as court rules Media Council Act constitutional' 27 May 2016 https://citizentv.co.ke/news/blow-to-media-as-court-rules-media-councilact-constitutional-128116 (accessed 10 July 2017).

123 Nyanjom (n 27 above) 10.

124 Nation Media Group Limited (n 121 above) para 17.

125 Kenya Correspondents Association 'High Court gives new date for hearing of case on controversial media laws' 7 August 2014 https://www.facebook.com/ KenyaCorrespondentsAssociation/posts/578377745622229 (accessed 9 July 2017).

126 Nation Media Group Limited (n 121 above) para 239(4).

127 Kenya Correspondents Association (n 125 above).

128 Murimi (n 122 above).

129 As above. 
Ironically although the judges found all the controversial sections listed above as constitutional, the judges found two other sections of the laws unconstitutional. ${ }^{130}$ The judges declared Section 3(2) of the MCA unconstitutional, to the extent that it requires that those to sit in the tribunal probing complaints against journalists must reflect interests of all sections of society. ${ }^{131}$ The judges said this provision limits the right to freedom of expression. ${ }^{132}$ Additionally, they declared Section $6(2)$ (c) of the MCA unconstitutional for being vague in its description as to what constitutes matters of national security. ${ }^{133}$ Although the issue of national security is of importance, the ruling was a major blow to media freedom in Kenya. ${ }^{134}$

\section{Extra-legal factors hampering media freedom in Kenya}

The government has not only adopted legislative means to interfere with media freedom in Kenya as is illustrated above, it has also adopted non-legislative methods of control in order to muzzle the media. ${ }^{135}$ Consequently, 'what you get is not always all there is to know ... Doublespeak is the name of the game!'136

\subsection{Media ownership}

The media is a very powerful tool especially in Kenya where it is rated as one of the most trusted institutions. ${ }^{137}$ As a result it remains the main source of information, and its role as a forum for public discussion and debate has always been recognised by politicians and Kenyan citizens. ${ }^{138}$ Essentially, whoever controls the media has the power because they control the narrative that is sold to the people. This is why politicians like former President Daniel Moi, current president Uhuru Kenyatta, politician Kenneth Matiba and many others, tried by all means to have some influence on the media companies, through ownership of the media groups or by funding. ${ }^{139}$

It is worth noting, is that although Kenya's Information and Communications Act empowers the Communications Authority to

130 Nation Media Group Limited (n 121 above) para 239(3)i \& 239(3)ii.

131 Nation Media Group Limited (n 121 above) para 239(3)i.

$132 \mathrm{~J}$ Kadida 'Blow to media as court declares "draconian laws" constitutional' 27 May 2016 http://www.the-star.co.ke/news/2016/05/27/blow-to-media-ascourt-declares-draconian-laws-constitutional_c1359056 (accessed 4 July 2017).

133 Nation Media Group Limited (n 94 above) para 239(3)ii.

134 Kadida (n 132 above).

135 Nyanjom (n 27 above) 15.

136 Nyanjom (n 27 above) 6.

137 Mutunga (n 20 above).

138 Obiero (n 10 above) 23.

139 As above. 
either issue or deny frequency licenses to both individual and institutional applicants, it fails to provide clear safeguards against political favouritism in the allocation of frequencies. ${ }^{140}$

Furthermore, the government has always maintained tight control over the allocation of radio and television frequency licenses and as a result, the broadcasting sector in Kenya has largely been dominated by individuals close to government. ${ }^{141}$ For example, state-owned Kenya Broadcasting Corporation (KBC) - both radio and television was the sole broadcaster until 1989 when then - President Daniel Moi and his political allies established the first private television station, Kenya Television Network (KTN). ${ }^{142}$ This was at a time when the government denied frequency licenses to other applicants for private television and radio stations. 143

During former President Mwai Kibaki term, Ali Chirau Mwakwere, whose family operates Kaya FM at the coast, and Koigi Ameer, who owns Sauti Yes Mwananchi Radio and TV Ltd in the Rift Valley, acquired frequency licenses when they both served as ministers in his government between 2003 and 2007. Samuel Poghisio, whose wife owns Elgonet Communication Technologies Ltd, which operates a radio station in the Rift Valley, acquired frequency licences while he served as Information and Communications Minister under President Kibaki between 2007 and 2013. ${ }^{144}$

Currently in Kenya five big media groups own and operate the nation's 22 television stations. The groups are: (1) KTN, owned by the family of former president Moi; (2) NTV, which is part of the Nation Media Group (NMG) of which the Aga Khan, the global spiritual leader of Shia Ismaili Muslims, is the largest individual shareholder; (3) the government-owned Kenya Broadcasting Corporation (KBC) (which also by 2012 had 85 of the 300 radio frequencies operational or on air); (4) K24, owned by the family of President Uhuru Kenyatta; and (5) Citizen TV owned by Royal Media Services of Samuel K. Macharia, a businessman and politician. ${ }^{145}$ Additionally, all the five major television operators mentioned above also operate radio stations with considerable geographic reach, which means that, unlike all the other media houses, each of the five have countrywide coverage. ${ }^{146}$

When it comes to print, the media companies which dominate in TV and radio also make an appearance here. Kenya has for decades been dominated by the Daily Nation and its weekend editions, all owned by NMG of the Aga Khan and the Standard newspapers that is

140 Namwaya (n 38 above) 15.

141 Namwaya (n 38 above) 16.

142 Namwaya (n 38 above) 15.

143 As above.

144 Namwaya (n 38 above) 16.

145 As above.

146 Namwaya (n 38 above) 16-17. 
predominantly owned by the family of former President Moi, whose family has publicly supported President Kenyatta. The other two daily newspapers, The Star, is owned by Radio Africa Group, closely associated with Kiprono Kitony, a relative of former President Moi, and The People, owned by the Kenyatta family. ${ }^{147}$

As a result of the control that the government has over Kenyan media, there was a blanket media 'blackout' on the coverage of the opposition Coalition for the Restoration of Democracy party's Saba Saba rally on 7 July 2014 arose from a Communications Authority (CA) threat to 'take the necessary regulatory action, including the withdrawal of frequencies from offending stations.'148

Media ownership has led some to question the authenticity of media houses and their reporting. ${ }^{149}$ This is because whoever owns the media house has to some extent, discretionary powers over what is to be reported to the masses. This creates a problem as information maybe be presented in such a way as favouring one party rather than an objective approach to news coverage. ${ }^{150}$

\subsection{Advertising}

Another non legislative method employed by the government to muzzle the Kenyan media is through advertising. Interestingly enough National governments remains the single largest source of revenue for news organisations in Africa. In Rwanda, for example, a staggering 85 to 90 percent of advertising revenue comes from the public sector. ${ }^{151}$

In Kenya, it is estimated that 30 percent of newspaper revenue comes from government advertising. ${ }^{152}$ An example of just how much power the Kenyan government has over media revenue is illustrated by a 2013 incident where the government spent 40 million Kenyan Shillings (USD 387,578 ) in two weeks just to publish congratulatory messages for the new President Uhuru Kenyatta. ${ }^{153}$

With 8 August 2017 elections fast approaching, the Kenyan government decided to stop advertising in local commercial media. ${ }^{154}$

147 Namwaya (n 38 above) 17.

148 Nyanjom (n 27 above) 6.

149 Namwaya (n 38 above) 17.

150 Kipngetich (n 52 above) 40.

$151 \mathrm{G}$ Ogola 'How African governments use advertising as a weapon against media freedom' 23 April 2017 https://www.standardmedia.co.ke/business/article/ 2001237400/how-african-governments-use-advertising-as-a-weapon-againstmedia-freedom (accessed 10 July 2017).

152 Ogola (n 151 above)

153 As above.

154 Namwaya (n 38 above) 40 - 41. 
On 8 February 2017, Kenyan authorities banned government ministries, departments, and agencies from placing state advertisements in private media. ${ }^{155}$ President Kenyatta's Chief of Staff and Head of the Civil Service, Joseph Kinyua, directed state accounting officers responsible for placing government advertisements, to advertise only in a new government publication, My.Gov, which was initially created in 2015 as an online portal. ${ }^{156}$

Currently the government publication is now being published as paid inserts in the four newspapers, The Daily Nation, The Standard, The Star newspaper and People Daily, the latter owned by the Kenyatta family.

A coincidence? It's difficult not to characterise the withdrawal of state advertising from commercial media as punitive. ${ }^{158}$ The revenue stream provided by government is very important and without it, newspapers are likely to close shop like in Serbia, Hungary, Namibia, Lesotho and Swaziland. ${ }^{159}$

Nevertheless, the government argued that the move was part of an initiative to curb runaway spending by lowering the advert spend in Kenya's mainstream media and directing all the money to the new title. 160

A similar move was made in South Africa last year when the government's communications arm announced that it would scale down government advertising in local commercial media. ${ }^{161}$ Instead, advertisements would be carried in the government newspaper Vuk'uzenzele. The decision withdrew an estimated USD \$30 million from the country's commercial newspaper industry. ${ }^{162}$ Like Kenyan, the South African government also claimed that the move was made to reduce government spending. But critics have argued that the decision was made to punish a media outlet that's been particularly critical of President Jacob Zuma's presidency. ${ }^{163}$

When the government withdraws government advertising from commercial media, it can be interpreted as a way to undermine the freedom of expression. Starving news media of revenue is a means of indirect state control. ${ }^{164}$

155 As above.

156 Nyanjom (n 27 above).

157 Ogola (n 151 above).

158 Namwaya (n 38 above) 41.

159 Ogola (n 151 above).

160 As above.

161 As above.

162 As above.

163 As above.

164 As above. 


\subsection{Threats and attacks against journalists}

There have also been an increase in threats and attacks on journalists who are critical of the government. ${ }^{165}$ Organisations have documented 17 separate incidents in Kenya, in which 23 journalists and bloggers were physically assaulted between 2013 and 2017 by government officials or individuals believed to be aligned to government officials. ${ }^{166}$ Of these, at least two died under circumstances that may have been related to their work. ${ }^{167}$ Furthermore, 16 incidents have been documented of direct death threats against journalists and bloggers across the country in the same period. ${ }^{168}$ Police has also arbitrarily arrested, detained, and later released at least 14 journalists and bloggers. ${ }^{169}$ Despite receiving formal complaints from journalists, the police have rarely investigated the attacks or threats. ${ }^{170}$ There is no evidence that any state actor has in the past five years been held accountable for threatening, intimidating, or physically attacking a journalist or blogger in Kenya. ${ }^{171}$

Kenyan authorities have often invoked alleged national security concerns as a basis to obstruct free expression and access to information. While national security can be a basis for limiting free expression under internationally accepted principles, governments must use the least restrictive means possible in prohibiting such speech and the national security interests should be legitimate. ${ }^{172}$

\section{Media freedom and the Kenyan General Election (2017)}

Media freedom recently came into sharp focus during the campaign trail and Kenyan General Election held on 8 August 2017 election. ${ }^{73}$ Kenyan citizens on various platforms accused local media and journalists of bias in their role of informing the public, with some critics claiming that local media had failed in carrying out its major functions in playing the watchdog role during the 2017 Kenyan elections. ${ }^{174}$ Even before the Election Day, the Kenya Television

165 Namwaya (n 38 above) 27.

166 As above.

167 Namwaya (n 38 above) 2.

168 Namwaya (n 38 above) 3.

169 As above.

170 As above.

171 As above.

172 As above.

173 T Makokha 'Kenyans accuse local media of biased reporting' 12 August 2017 https://www.standardmedia.co.ke/article/2001251105/kenyans-accuse-localmedia-of-biased-reporting (accessed 24 August 2017).

174 As above. 
Network (KTN), one of the leading traditional media houses in Kenya, was accused of under-representing the policy of opposition in Kenya and openly supporting the Jubilee government ahead of the 2017 general election in August. ${ }^{175}$ The broadcaster came under fire from social media users who suggested that a series of distorted news reports it ran discriminated against the opposition party, National Super Alliance (NASA) and that the reports designed to deliberately condition the mind of voters and ultimately shape their opinions on key campaign issues and the respective candidates. ${ }^{176}$ This further lead to some Kenyans on Twitter (popularly known as \#KOT) running a hashtag labelled '\#PartisanPressKE' which trended on Twitter on 19 June. ${ }^{177}$ On 13 August 2017, NASA told its supporters to boycott the Nation Media Group newspapers and television, alleging bias. ${ }^{178}$

On 12 August 2017, despite concerns about the authenticity of the results by the opposition, the Independent Electoral and Boundaries Commission declared President Uhuru Kenyatta the winner of the presidential race. ${ }^{179}$ This led to a weekend of protests and riots, particularly in the opposition strongholds. ${ }^{180}$ Interesting enough, media reports on the protest were scant, in fact one would not be faulted for claiming the local media gave the whole incident a blackout for almost two days. ${ }^{181}$ However, as the weekend wore on, it became clear that all was not well in Kenya. The opposition coalition, in a press statement on Saturday, claimed that 100 people had been killed by police officers in the post-election violence, while the Kenya National Commission on Human Rights placed the number at $24 .{ }^{182}$ This confusion was fuelled by the fact that mainstream media chose not to cover the incident. There were even complaints that local journalists were not reporting what innocent Kenyans were going through at the hands of the police, and were instead airing children's shows on TV. ${ }^{183}$

175 'Media terrorism exposed: Public outraged by KTN's open hostility against Raila Odinga and NASA' 21 June 2017 https://www.kenya-today.com/news/mediaterrorism-exposed-ktn-tv-accused-structural-bias-raila-odinga-nasa (accessed 24 August 2017).

176 As above.

177 As above.

178 K Houreld \& E Cropley 'Kenya opposition leader defies pressure to concede defeat' 13 August 2017 https://www.reuters.com/article/us-kenya-electionidUSKCN1ATOBY(accessed 23 July 2017).

179 N Sambuli 'How Kenya became the latest victim of "fake news"' 17 August 2017 http://www.aljazeera.com/indepth/opinion/2017/08/kenya-latest-victim-fakenews-170816121455181.html17 (accessed 25 August 2017).

180 As above.

181 As above.

182 As above.

183 C Muganda, 'Media accused of not playing watchdog role' 20 August 2017 https: // wWw.standardmedia.co.ke/article/2001251955/media-accused-of-not-playingwatchdog-rolehttps: //www.standardmedia.co.ke/article/2001251955/mediaaccused-of-not-playing-watchdog-role_(accessed 25 August 2017). 
As all this played out, many Kenyans, who were not satisfied with the mainstream media's limited coverage of the situation, were glued to social media channels for updates. ${ }^{184}$ Mainstream media eventually began to cover the stories, but only after international media had beat them to the task. ${ }^{185}$ When the local mainstream media eventually began coverage of police brutality on those who were protesting the Kenyan elections, reports of complaints of harassment against journalists by police began powering in. ${ }^{186}$ For example, on 12 August 2017, KTN journalist Duncan Khaemba was arrested whilst reporting on violent post-election protests in Nairobi's Kibera slum. ${ }^{187}$ Additionally, Matina Stevis, Africa correspondent for The Wall Street Journal, told the Committee to Protect Journalists (CPJ) that a police officer hit her over the head with a wooden stick on 12 August $2017 .{ }^{188}$ In the western city of Kisumu, an opposition stronghold, police officers blocked journalists from approaching demonstrators. ${ }^{189}$ Nation Media photographer, Dennis Onsongo, stated someone stole his lens as he moved through a crowd to the aftermath of a child's death in post-election protests in the Mathare area of Nairobi. ${ }^{190}$

\section{Conclusion}

The challenges facing the media, as detailed above, are not unique to Kenya. Around the world, concerns have been raised about the impact of concentration and commercialisation of the quality of the media, and the consequences of this on its ability and willingness to hold power to account. ${ }^{191}$ The Kenyan regulatory environment is still hostile to media freedom. Furthermore, while the Constitution of Kenya is very firm on protecting media freedom, various intervening factors have so far acted to undermine the extent of the realisation of this freedom. It is thus possible to make a few general observations about media freedom in Kenya.

Firstly, from the above there seems to be a lack of strong political will to fully implement the Constitution or to amend parts of it as necessary. There have been various instances of violations of the Constitution in general and of media freedom specifically, including the half-hearted attempt to review media laws in Kenya as provided

184 As above.

185 As above.

186 Committee to Protect Journalist, 'Kenyan journalists harassed, detained reporting on election violence' 17 August 2017 https://cpj.org/2017/08/kenyanjournalists-harassed-detained-reporting-on-.php (accessed 25 August 2017).

187 As above.

188 As above.

189 As above.

190 As above.

191 Ali (n 19 above). 
in 5th Schedule of the Constitution and the failings evident in the adaptation of the KICA and the MCA. ${ }^{192}$

While there are those who may argue that media freedom is not absolute, a true fact protected by the Constitution, nevertheless if the government wants to limit media freedom in Kenya for whatever reason, then it should do it through legal channels in order to avoid constitutional challenges. The Constitution provides for the limitation of rights and fundamental freedom. A right or fundamental freedom in the Bill of Rights, in this case media freedom shall not be limited except by law, and only to the extent that the limitation is reasonable and justifiable in an open and democratic society based on human dignity, equality and freedom, taking into account all relevant factors. Additionally, a limitation is only valid if one of the following conditions are met: (1) the legislation specifically expresses the intention to limit that right or fundamental freedom, and the nature and extent of the limitation; (2) the provision is clear and specific about the right or freedom to be limited and (3) the nature and extent of the limitation; and shall not limit the right or fundamental freedom so far as to derogate from its core or essential content. ${ }^{193}$

As it stands the Kenyan government seems to be engaged in a cat and mouse game where it gives with one hand and takes with the other. The government has been claiming to uphold the Constitution with one hand and with the other using both legislative and nonlegislative means to muzzle the Kenyan media. ${ }^{194}$ It is evident that Kenya still has a long way to go when it comes to media freedom.

192 Nyanjom (n 27 above) 29.

$193 \mathrm{Sec} 14$ of the Constitution of Kenya, 2010.

194 G Gathigi 'How the media covered Kenya's General Election' 10 August 2012 https: / theconversation.com/how-the-media-covered-kenyas-general-election82324 (accessed 24 August 2017). 